\title{
Evaluation of Analgesic, Antidiarrheal and Anti-hyperglycemic Activities of Dactyloctenium australe (Poaceae)
}

\author{
Md. Enamul Hoque ${ }^{1}$, Md. Akbar Hossain ${ }^{2}$ and Md. Sohel Rana ${ }^{1}$ \\ ${ }^{1}$ Department of Pharmacy, Jahangirnagar University, Savar, Dhaka, Bangladesh \\ ${ }^{2}$ Department of Pharmacy, ASA University Bangladesh, Dhaka, Bangladesh
}

(Received: November 10, 2018; Accepted: December 23, 2018; Published: January 17, 2019)

\begin{abstract}
Dactyloctenium australe belongs to the family of Poaceae. It is also called gramineae or true grasses. Poaceae is the fifth largest family of flowering plants. The current study was conducted on methanol extract of the aerial parts of $D$. australe (MEDA) to evaluate its in vivo analgesic activity by acetic acidinduced writhing method in mice. The plant extract was also evaluated for antidiarrheal and antihyperglycemic activities using castor oil-induced diarrhea and oral glucose tolerance test, respectively. In acetic acid-induced writhing test, the extract showed $52.18 \%$ and $62.40 \%$ inhibition of writhing at the doses of $200-400 \mathrm{mg} / \mathrm{kg}$ body weight, respectively while standard aspirin at the dose of $50 \mathrm{mg} / \mathrm{kg}$ bw showed $58.12 \%$ writhing inhibition. In anti-hyperglycemic test, the extract revealed its activity in a dose dependent manner. In antidiarrheal activity test, the extract exhibited $48.54 \%$ and $72.92 \%$ inhibition of defecation at the doses of $250-500 \mathrm{mg} / \mathrm{kg}$ bw, respectively whereas the standard loperamide $(3 \mathrm{mg} / \mathrm{kg}$ bw) displayed $70.24 \%$ inhibition of defecation.
\end{abstract}

Key words: Dactyloctenium australe, analgesic, antidiarrheal, anti-hyperglycemic.

\section{Introduction}

A medicinal plant is any plant which contains substances that can be used for therapeutic purposes or which is a precursor for synthesis of useful drugs (Sofowora, 1982). Chemical principles from natural sources have become much simpler and have contributed significantly to the development of new drugs from medicinal plants (Meena et al., 2010). Traditional medicines are very important since early ancient period because of their faithfulness in the use against various ailments and human sufferings. Different types of bioactive natural compounds are derived from medicinal plants and they serves as raw materials for new drug discovery (Ramawat et al., 2009). In last few years, there has been great focus on the possible health benefits of natural substances with antioxidant, antimicrobial, analgesic, anticancer, antidiabetic and others activities. This has resulted in an enormous increase of research on different medicinal plants to find lead compounds responsible for such pharmacological activities.

Dactyloctenium australe is a $32-80 \mathrm{~cm}$ long evergreen creeping perennial grass species, which belongs to the family Poaceae (Gräser). The Poaceae (also called Gramineae, Durban Grass or true grasses) are a large family of flowering plants. Poaceae is the fifth-largest plant family, following the Orchidaceae, Asteraceae, Fabaceae, and Rubiaceae (Firth et al., 2002).

Among different disorders, diarrhea is one of the causes of morbidity and mortality especially in developing countries (Carlos and Saniel, 1990). The World Health Organization (WHO) has established a diarrhea disease control program for the treatment and management of diarrhea that includes traditional medicine practices along with health education and prevention approaches, which is mostly based on herbal products (WHO, 2015). WHO has accepted

Correspondence to: Md. Sohel Rana; Tel: +88-01711987016; Email: sohelrana.ju@ gmail.com 
traditional medicine as an alternative health care form. In a developing country like Bangladesh, where a handsome amount of people including children are affected by diarrhea every year, the search for plants with antidiarrheal activity that could be used against diarrheal disease is of prime interest.

Some antidiabetics have serious side effects and deleterious contraindications. Hence, researchers are paying attention to herbal medications having high therapeutic efficacy with minimal side effects. The antidiabetic agents from medicinal plants are very promising and traditionally acclaimed medicinal plants are being investigated for their antidiabetic potential (Babu et al., 2002; Parthasarathy et al., 2009). In other studies, the crude extracts of some medicinal plants were evaluated for alpha-amylase, alpha-glucosidase, total phenolic and total flavonoid contents where the extract have shown significant anti-hyperglycemic and analgesic activities (Das et al., 2012; Sangeetha et al., 2012; Telagari et al., 2015). In this context, we hypothesize that the leaf extracts of this plant might possess some compounds with anti-hyperglycemic, antidiarrheal and analgesic activities.

\section{Materials and Methods}

Collection of plant material: The aerial parts of $D$. australe were used as the raw material for the extraction and other investigation process. The plant sample was collected from Sylhet, Bangladesh in April, 2016. Any types of undesirable materials or plants or plant parts were separated from the collected plant parts. The plant was identified in Bangladesh National Herbarium, Dhaka, where a voucher specimen (Accession number: DACB12771) has been deposited.

Drying and grinding: The collected plant materials were washed with water. After washing it was subjected to shed-drying for 1-2 weeks. When the plant parts were suitable for grinding, it was ground to a coarse powder by a grinder (Wuhu motor factory, China). Finally, the powder material was stored in a sealed container and kept in a dark, cool and dry place until farther processing.
Cold extraction: About $700 \mathrm{~g}$ of finely powered plant materials was taken in a clean glass container and it was soaked in $1500 \mathrm{~mL}$ of methanol. Then the container was sealed and kept for a period of 15 days. During this time, it was subjected to occasional stirring and shaking. The mixture was then filtered by cotton. Finally, it was filtered by Whatman filter paper number 1 and concentrated to give methanol extract of D. australe (MEDA).

Experimental animals: About 4-5 weeks aged Swiss-albino mice of both sexes (70 mice), average weight of 20-35g was collected from central animal house of the Department of Pharmacy, Jahangirnagar University, Savar, Dhaka-1342 and were used for the present study. The animals were randomly selected and divided into normal and experimental groups. After one week for their adaptation, all the experimental processes was conducted and these were performed in an isolated and noiseless environmental condition. The animals were housed under standard laboratory conditions (relative humidity 55-65\%, room temperature $25.0 \pm 20{ }^{\circ} \mathrm{C}$, and $12 \mathrm{~h}$ light dark cycle) and fed with standard diet (icddr,b formulated) and had free access to tap water but were fasted $12 \mathrm{~h}$ prior to each experiment. The Federation of European Laboratory Animal Science Associations (FELASA) guidelines and recommendations were followed to reduce the pain and stress of the experimental mice.

Acetic acid-induced writhing test: The peripheral analgesic activity of the samples was evaluated in mice using acetic acid-induced writhing method (Koster et al., 1959; Biswas et al., 2009; Hossain et al., 2016; Woolfe et al., 1969). Mice were divided into 4 groups of 5 mice in each group. The control group received $1 \%$ Tween 80 in normal saline (10 $\mathrm{ml} / \mathrm{kg}$ body weight), the standard group received Aspirin $(50 \mathrm{mg} / \mathrm{kg} \mathrm{bw})$ and the experimental groups received crude extract of $200-400 \mathrm{mg} / \mathrm{kg}$ bw. Forty minutes later, each mouse was injected with $1 \%$ acetic acid at a dose of $10 \mathrm{ml} / \mathrm{kg}$ bw. The number of writhing responses was recorded for each animal during a subsequent $5 \mathrm{~min}$ period after $10 \mathrm{~min}$ of intraperitoneal administration of acetic acid and the mean writhing for each group was obtained. 
The percentage inhibition was calculated using the formula -

$\%$ Inhibition $=\frac{\text { Mean number of writhing (control) }- \text { Mean number of writhing }(\text { drug })}{\text { Mean number of writhing (control) }} \times 100$

Evaluation of antidiarrheal activity: To evaluate castor oil-induced antidiarrheal activity of the extract, the experimental mice were also divided into four groups: two test groups, control and standard consisting of 5 mice in each group.Tween-80 (1\% in water) was given to the control group and the test groups of mice were given the extract at 200-400 $\mathrm{mg} / \mathrm{kg}$ bw. Loperamide ( $3 \mathrm{mg} / \mathrm{kg}$ bw) was used as the standard drug. After 60 minutes, each mouse of all groups was administered $0.5 \mathrm{ml}$ of castor oil in oral route. All animals were then kept separately in transparent cage having white blotting paper in order to count the number of faces. Every hour the blotting paper was changed and it was observed for a period of 4 hours. Latent period of fecal drops and percent inhibition of defecation of each group were determined (Rahman et al., 2010; Hasan et al., 2017; Islam et al., 2013). By using the following formula the percent inhibition of defecation was calculated:

Percent inhibition $=\left(\mathrm{D}_{0}-\mathrm{D}_{1} / \mathrm{D}_{0}\right) \times 100 \%$

Where, $D_{0}$ is the number of defecation of the control group, and $D_{1}$ is the number of defecation of the test or standard group.

Evaluation of anti-hyperglycemic activity: To evaluate the anti-hyperglycemic activity of the extract, the experimental mice were also divided into four groups: two test samples, control and standard consisting of 5 mice in each group. The test groups of mice were given the extract at 250-, 500- and 1000 $\mathrm{mg} / \mathrm{kg}$ bw. Glibenclamide ( $5 \mathrm{mg} / \mathrm{kg}$ bw) was used as a standard drug. In a fasting state (having no food for at least 10 hours but not more than 16 hours), the experimental animals were tested. After selection and weighing of mice, fasting blood glucose level for control, standard and two test groups were measured. Then glucose solution was administered and blood glucose levels after 30, 60, and $150 \mathrm{~min}$ were measured (Kumar et al., 2006; Shirwaikar et al.,
2006; Kessler et al., 2005). To estimate blood glucose level, blood samples of experimental mice were drawn by pricking with a sterile needle in the tail vein. The blood glucose levels were measured by using the glucometer and compatible blood glucose strips. The blood glucose levels were measured in millimole per liter (mmol/l) unit.

Statistical analysis: The values are presented as mean \pm standard error of mean (SEM) and one-way ANOVA analysis was used to determine the significant difference between the control group and experimental groups, the $\mathrm{p}$ values $<0.05$ were considered to be statistically significant.

\section{Results and Discussion}

Acetic acid-induced writhing test: The results of the test showed that MEDA at the dose of 200-400 $\mathrm{mg} / \mathrm{kg}$ bw exhibit significant $(\mathrm{p}<0.01)$ inhibition of writhing reflex by $52.18 \%$ and $62.40 \%$, respectively while the standard (Aspirin, $50 \mathrm{mg} / \mathrm{kg}$ bw) drug was found to inhibit the writing response by $58.12 \%$ (Table 1).

Evaluation of antidiarrheal activity: In the castor oil-induced diarrhea, the MEDA at the doses of 200$400 \mathrm{mg} / \mathrm{kg}$ bw of mice significantly $(\mathrm{p}<0.001)$ decreased the total number of faeces as well as delayed the onset of diarrhea in a dose dependent manner. Percent inhibition of defecation at doses $200-400 \mathrm{mg} / \mathrm{kg}$ bw was 48.54 and 72.92 , respectively whereas that for the standard loperamide $(3 \mathrm{mg} / \mathrm{kg}$ ) was 70.24 (Table 2).

Evaluation of anti-hyperglycemic activity: The extract of $D$. australe showed significant $(p<0.02)$ anti-hyperglycemic activity on mice in a time dependent manner as compared to the control groups (Table 3). 
Plants are natural sources of diverse therapeutic activities (Raja et al, 2013). Accordingly, the crude drugs are getting much more acceptances in healthcare sector (Joshi et al., 2011). In pathological conditions, tissue injury causes pain resulting in the local release of chemical mediators such as prostaglandins, cytokinins, leukotrienes etc. They act on the nerve terminals in both activating them directly and enhancing their sensitivity to other stimulation (Kanodia et al., 2008; Goldstein et al.,
1970). Acetic acid administration through intraperitoneal routes can produce pain by consequent abdominal writhing due to the release of mediators like prostaglandin $\mathrm{E}_{2}$ and other lipooxygenase products (Sulaiman et al., 2008). Prostaglandin mainly prostacyclines $\left(\mathrm{PGI}_{2}\right)$ and prostaglandin E (PG-E) are responsible for pain sensation due to the excitation of ð-nerve fibers (Lourens et al., 2004; Islam et al., 2015). Thus, the extract of $D$. australe may produce non-narcotic

Table 1. Analgesic activity of methanol extract of $D$. australe leaves in acetic acid-induced pain in mice.

\begin{tabular}{lccc}
\hline Treatment $(n=5)$ & Dose $(\mathrm{mg} / \mathrm{kg})$ & No of writhes & \% Inhibition \\
\hline Control & $1 \%$ Tween-80 & $40.83 \pm 1.13$ & --- \\
Aspirin & 50 & $17.43 \pm 3.05^{*}$ & 58.12 \\
MEDA & 200 & $19.93 \pm 0.33^{*}$ & 52.18 \\
MEDA & 400 & $15.35 \pm 0.55^{*}$ & 62.40 \\
\hline
\end{tabular}

Values are expressed as mean \pm S.E.M $(n=5)$. $p<0.01$, compared with vehicle control (ANOVA followed by Dunnet's t-test).

Table 2. Effects of methanol extract of $D$. australe leaves on castor oil-induced diarrhea in mice.

\begin{tabular}{lcccc}
\hline Group & $\mathrm{n}$ & $\begin{array}{c}\text { Onset of diarrhea } \\
\text { (mean } \pm \text { SEM, min) }\end{array}$ & $\begin{array}{c}\text { Number of stools after 4 hrs } \\
\text { (mean } \pm \text { SEM) }\end{array}$ & $\begin{array}{c}\text { Inhibition of } \\
\text { defecation }(\%)\end{array}$ \\
\hline Control (1\% tween-80 water) & 5 & $33 \pm 3.59$ & $12.3 \pm 0.88$ & 70.24 \\
Standard (Loperamide $3 \mathrm{mg} / \mathrm{kg})$ & 5 & $197.4 \pm 2.65^{*}$ & $3.66+0.0014^{*}$ & 48.54 \\
MEDA 200 mg/kg bw & 5 & $101 \pm 3.64^{*}$ & $6.33+0.023^{*}$ & 72.92 \\
MEDA 400 mg/kg bw & 5 & $178.8 \pm 5.0^{*}$ & $3.33+0.74^{*}$ & \\
\hline
\end{tabular}

$* \mathrm{p}<0.001$ vs control group. SEM: standard error of mean. $\mathrm{n}=$ number of mice

Table 3. Effect of the methanol extract of $D$. australe leaves on oral glucose tolerance test (anti-hyperglycemic activity test) in normal control mice.

\begin{tabular}{lccccc}
\hline \multirow{2}{*}{ Group $(\mathrm{n}=5)$} & \multicolumn{5}{c}{ Blood glucose level (mean \pm SEM) } \\
\cline { 2 - 5 } & $0 \mathrm{~min}$ & $30 \mathrm{~min}$ & $60 \mathrm{~min}$ & $120 \mathrm{~min}$ & $180 \mathrm{~min}$ \\
\hline Control & $6.2 \pm 0.4$ & $10.5 \pm 0.3$ & $7.3 \pm 0.6$ & $5.7 \pm 0.1$ & $7.05 \pm 0.55$ \\
Glibenclamide 5mg/kg* & $5.45 \pm 0.25$ & $4.8 \pm 0.1$ & $3.5 \pm 0.2$ & $1.7 \pm 0.2$ & $6 \pm 4$ \\
MEDA 250 mg/kg** & $4.05 \pm 0.75$ & $5 \pm 1.9$ & $5.55 \pm 0.55$ & $4.7 \pm 1.6$ & $4.2 \pm 0.0$ \\
MEDA 500 mg/kg*** & $3.6 \pm 0.8$ & $4.8 \pm 1.2$ & $4.6 \pm 0.6$ & $4 \pm 1.7$ & $3.65 \pm 0.45$ \\
MEDA 1000 mg/kg**** & $5.85 \pm 0.65$ & $4.45 \pm 1.45$ & $4.15 \pm 0.15$ & $5.55 \pm 0.45$ & $4.04 \pm 0.25$ \\
\hline
\end{tabular}

Here, $* \mathrm{p}=0.0276, * * \mathrm{p}=0.0169, * * * \mathrm{p}=0.2868, * * * * \mathrm{p}=0.6014$ vs Control group. SEM: standard error of mean. 
analgesic activity due to the inhibition of prostaglandin synthesis by blocking of lipooxygenase and cyclooxygenase activities. In the present study, the methanolic extract of $D$. australe showed significant $(\mathrm{p}<0.01)$ writhing inhibitions compared to that of standard aspirin. The result also showed that percentage of writhing inhibition in two test samples (250-500 mg/kg bw) are sufficient enough to produce analgesic activity as compared to standard test results (Table 1). It is clear that the standard drug aspirin is a potent analgesic and it can produce stronger analgesic activity rather the methanolic extract of $D$. australe.

Several studies have shown that many medicinal plants have shown bioactivities, for instance, delay or suppress gut motility, intestinal transit, stimulate water absorption or reduce intraluminal fluid accumulation (Gutierrez et al., 2013). Diarrhea refers to excess passage of watery stools which is caused by decreased consistency or increased frequency of bowel movements. The possible mechanism of diarrhea would be the change in active ion transport system either by increasing chloride secretion or decreasing sodium absorption. It may also include the increase in luminal osmolality, change in intestinal motility and increase in tissue hydrostatic pressure (Schiller, 1995). Among all the mechanisms, castor oil (active compound ricinoleic acid) induces diarrhea by stimulating intestinal motility and secretory processes, is the major one (Neimegeers et al., 1984). In the present study, antidiarrheal activity of the plant extract of $D$. australe was investigated by castor oil-induced diarrhea in mice. The result showed that MEDA significantly $(\mathrm{p}<0.001)$ expressed antidiarrheal activity in a dose dependent manner that makes it more similar with other plant extracts (Table 2) (Umer et al., 2013).

Diabetes is a metabolic disorder that indicates elevated blood glucose concentration and occurred by insufficient insulin secretion and action (Henriksen, 2001; Schroeder and Kolterman, 2010). The agents that are used to treat diabetes by means of decreasing blood glucose concentration or sufficiently secreting insulin are known as anti-hyperglycemic agents. As per reference of Joy and Kuttan, (1999) the mechanism of anti-hyperglycemic agents had either by potentiating pancreatic insulin secretion or increasing glucose uptake. Such mechanism has also been proposed in another study, root extracts of Helicteres isora (Venkatesh et al., 2004). The current study with methanolic extract of $D$. australe expressed significant $(\mathrm{p}<0.001)$ anti-hyperglycemic activity as compared to control and other groups (Table 3). The possible mechanism of this activity may be either by potentiating pancreatic insulin secretion or increasing glucose uptake. The results also demonstrate that animals treated with standard drug (Glebenclamide $5 \mathrm{mg} / \mathrm{kg}$ bw) has shown strong anti-hyperglycemic activity rather than the other groups and the two test groups $(250-500 \mathrm{mg} / \mathrm{kg} \mathrm{bw})$ also revealed significant decrease in blood glucose level. From the above discussion, we can say, that the MEDA may be a potential source of antihyperglycemic agents.

\section{Conclusion}

The present study summarizes analgesic, antidiarrheal and anti-hyperglycemic activities of $D$. australe leaf extract. However, further studies are necessary to explain the probable mechanisms related with these bioactivities.

\section{Acknowledgments}

The authors are thankful to the Department of Pharmacy, State University of Bangladesh for providing laboratory facilities and instrumental support. Special thanks to the authority of "International Centre for Diarrheal Disease and Research, Bangladesh" (icddr,b) for providing experimental mice.

\section{References}

Babu, V., Gangadevi, T. and Subramanian A. 2002. Antihyperglycemic effect of Cassia keinii leaf extract in glucose feed normal rats and alloxan induced diabetic rats. Indian J. Pharmacol. 34, 409-415. 
Biswas, M., Biswas, K., Ghosh, A.K. and Haldar, P.K. 2009. A Pentacyclic triterpenoid possessing analgesic activity for the fruit of Dregea volubilis. Pharmacog. Mag. 5, 90-92.

Carlos, C.C. and Saniel, M.C. 1990. Etiology and epidemiology of diarrhea. Phil. J. Microbiol. Infect. Dis. 19, 51-3.

Das, S., Das, S. and De, B. 2012. In vitro inhibition of key enzymes related to diabetes by the aqueous extracts of some fruits of West Bengal, India. Curr. Nutr. Food Sci. 8, 19-24.

Domaj. M.I., Glassco, W., Aceto, M.D. and Martin. B.R. 1999. Antinociceptive and pharmacological effects of metanicotina, a selective nicotine agonist. $J$. Pharmacol. Exp. Ther. 291, 390-398.

Firth, D.J. et al. 2002. Selection of pasture species for groundcover suited to shade in mature macadamia orchards in subtropical Australia Trop. Grasslands, 36, 1-12.

Goldstein, A., Aronow, L. and Kalman, S.M. 1970. Principles of Drug Action. The Basis of Pharmacology. J. Med. Chem.13, 337-337.

Gutierrez, S.P., Mendoz, D.Z., Munive, A.H., Martínez, A.M., Gonzalez, C.P. and Mendoza, E.S. 2013. Antidiarrheal activity of 19-deoxyicetexone isolated from Salvia ballotiflora Benth in mice and rats. Molecules. 18, 8895-8905.

Hasan, M.M., Hossain, A., Shamim, M.A. and Rahman, M.M. 2017. Phytochemical and pharmacological evaluation of ethanolic extract of Lepisanthes rubiginosa L. leaves. BMC Complem. Altern. Med. 17, 496.

Henriksen, E.J. 2001. Therapeutic Effects of Lipoic Acid on Hyperglycemia and Insulin Resistance, $2^{\text {nd }}$ ed. University of Arizona College of Medicine, Tucson, Arizona.

Hossain, A., Islam, T., Saifuzzaman, Saeed, M.A.S., Islam, M.K., Murshid, G.M.M. and Rahman, M.M. 2016. Bioactivity of Boehmeria macrophylla (Urticaceae) leaf extract. Orien. Pharm. Exp. Med. 16, 233-241.

Islam, F., Hossain, A., Hossain, M.G., Murshid, G.M.M. and Rahman, M.M. 2015. Evaluation of antioxidant, analgesic and cytotoxic activities of Typha angustata L. Root. Dhaka Univ. J. Pharm. Sci. 14, 55-59.

Islam, M.K., Mahmud, I., Saha, S., Sarker, A.B., Mondal, H., Monjur-Al-Hossain, A.S.M. and Anisuzzman, M. 2013. Preliminary pharmacological evaluation of Alocasia indica Schott tuber. J. Integr. Med. 11, 343351.
Joshi, B., Sah, G.P., Basnet, B.B., Bhatt, M.R., Sharma, D., Subedi, K., Pandey, J. and Malla, R. 2011. Phytochemical extraction and antimicrobial properties of different medicinal plants: Ocimum sanctum (Tulsi), Eugenia caryophyllata (Clove), Achyranthes bidentata (Datiwan) and Azadirachta indica (Neem). J. Microbiol. Antimicrob. 3, 1-7.

Joy, K.L. and Kuttan, R.J. 1999. Anti-diabetic activity of Picrorrhiza kurroa extract. 67, 143-148.

Kanodia, L. and Das, S. A. 2008. Comparative study of analgesic property of whole plant and fruit extracts of Fragaria vesca in experimental animal models. British J. Pharmacol. 4, 35-38.

Kessler, R.C., Chiu, W.T. and Demler, O. 2005. Prevalence, severity, and co-morbidity of 12-month DSM-IV disorders in the national co-morbidity survey replication. Arch. Gen. Psychiatry. 62, 617-27.

Koster, R., Anderson, M. and Beer, E.J. 1959. Acetic acid analgesic screening. Fed. Proc. 18, 418-420.

Kumar, G.P., Arulselvan, S.P. and Kumar, D.S. 2006. Antidiabetic activity of fruits of Terminalia chebulaon streptozotocin induced diabetic rats. J. Health Sci. 52, 283-291.

Lourens, A.C.U., Reddy, D., Baser, K.H.C., Viljoen, A.M. and Van Vuuren, S.F. 2004. In vitro biological activity and essential oil composition of four indigenous South African Helichrysum species. J. Ethnopharmacol. 95, 253-58.

Meena, A.K. and Rao, M.M. 2010. Folk herbal medicines used by the Meena community in Rajasthan. Asian J. Trad. Med. 5, 19-32.

Eddy, N. B. and Leimbach, D. 1953. Synthetic analgesics. II. Dithienylbutenyl-and dithienylbutylamines. $J$. Pharmacol. Exp. Ther. 107, 385-393.

Neimegeers, C.T.E, Awouters, F. and Janssen P.A.J. 1984. The castor oil test in rats: an in vivo method to evaluate antipropulsive and antisecretary activity of antidiarrheals. Drug Dev. Res. 4, 223-2277.

Parthasarathy, R., Ilavarasan, R. and Karrunakaran, C.M. 2009. Antidiabetic activity of Thespesia populnea bark and leaf extract against streptozotocin induced diabetic rats. Int. J. Pharm. Tech. Res. 1, 1069-1072.

Rahman, A., Riyanto, S., Yuniarti, N., Saputra, W.R., Utami, R. and Mulatsih, W. 2010. Antioxidant activity, total phenolic and total flavonoid of extracts and fractions of red fruit (Pandanus conoideus Lam). Int. Food Res. J. 17, 97-106.

Raja, R.R.Y., Krishna, K.C., Lokanatha, O., Mamatha, S. and Damodar, R.C. 2013. Antimicrobial activity of Azadirachta indica (neem) leaf, bark and seed extracts. Int. J. Res. Phytochem. Pharmacol. 3, 1-4. 
Ramawat, K.G., Das, S. and Mathur, M. 2009. The chemical diversity of bioactive molecules and therapeutic potential of medicinal plants, in: Ramawat, K.G. (Eds.), Herbal drugs: ethnomedicine to modern medicine. Berlin: Springer. pp. 7-32.

Sangeetha, R. and Vedasree, N. 2012. In vitro $\alpha$-amylase inhibitory activity of the leaves of Thespesia populnea. ISRN Pharmacology. 4. doi:10.5402/ 2012/515634

Schroeder, B.E. and Kolterman, O. 2010. The Role of Incretins in Insulin Secretion, In: Poretsky, L., (Eds.), Principles of Diabetes Mellitus, $2^{\text {nd }}$ ed., Springer, New York. 57-74.

Schiller, L.R. 1995. Review article: anti-diarrheal pharmacology and therapeutics. Aliment. Pharmacol. Ther. 9, 87-106.

Shirwaikar, A., Rajendran, K. and Barik, R. 2006. Effect of aqueous bark extract of Garuga pinnata Roxb in streptozotocin-nicotinamide induced type-II diabetes mellitus. J. Ethnopharmacol. 107, 285-290.

Sofowara, A. 1982. Medicinal Plants and traditional medicine in Africa. John Wilay \& Sons Limited, New York. 13, 37-40.
Sulaiman, M.R., Hussain, M.K., Zakaria, Z.A., Somchit, M.N., Moin, S., Mohamad, A.S. and Israf, D.A. 2008. Evaluation of the antinociceptive activity of Ficus deltoidea aqueous extract. Fitoterapia. 79, 557-561.

Telagari, M. and Hullatti, K. 2015. In vitro $\alpha$-amylase and $\alpha$-glucosidase inhibitory activity of Adiantum caudatum Linn. and Celosia argentea Linn. extracts and fractions. Indian J. Pharmacol. 47, 425-429.

Umer, S., Tekewe, A. and Kebede, N. 2013. Antidiarrhoeal and antimicrobial activity of Calpurnia aurea leaf extract. BMC Complement. Altern. Med. 13, 21.

Venkatesh, S., Reddy, G.D., Reddy, Y.S.R, Sathyavathy, D. and Reddy, B.M. 2004. Effect of Helicteres isora root extracts on glucose tolerance in glucose-induced hyperglycemic rats. Fitoterapia. 75, 364-367.

World Health Organization, Research guidelines for evaluating safety and efficacy of herbal medicine. Manila: World Health Organization; 1993. [Online] Available from: http://apps.who.int/medicinedocs/fr/d/Jh2946e/ [Accessed on 5 January, 2015]

Woolfe, G. and MacDonald, A.D. 1969. The evaluation of analgesic action of pethidine hydrochloride. $J$. Pharmacol. Exp. Therapeu. 166, 96-103. 